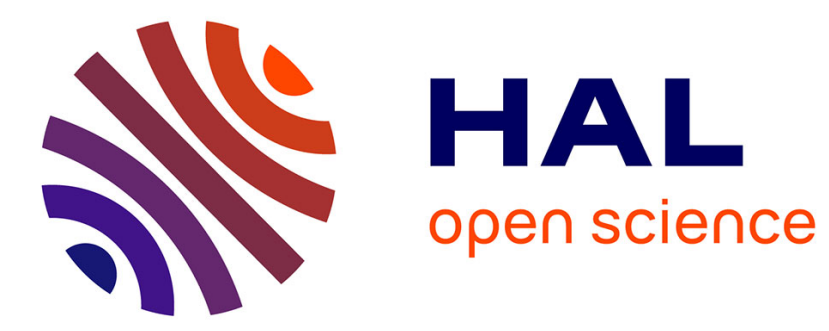

\title{
High-resolution stratigraphic forward modeling of a Quaternary carbonate margin: Controls and dynamic of the progradation
}

Jean Busson, Philippe Joseph, Thierry Mulder, Vanessa Teles, J. Borgomano, Didier Granjeon, C. Betzler, E. Poli, M. Wunsch

\section{To cite this version:}

Jean Busson, Philippe Joseph, Thierry Mulder, Vanessa Teles, J. Borgomano, et al.. High-resolution stratigraphic forward modeling of a Quaternary carbonate margin: Controls and dynamic of the progradation. Sedimentary Geology, 2019, 379, pp.77-96. 10.1016/j.sedgeo.2018.11.004 . hal02196904

\section{HAL Id: hal-02196904 \\ https://hal-ifp.archives-ouvertes.fr/hal-02196904}

Submitted on 29 Jul 2019

HAL is a multi-disciplinary open access archive for the deposit and dissemination of scientific research documents, whether they are published or not. The documents may come from teaching and research institutions in France or abroad, or from public or private research centers.
L'archive ouverte pluridisciplinaire HAL, est destinée au dépôt et à la diffusion de documents scientifiques de niveau recherche, publiés ou non, émanant des établissements d'enseignement et de recherche français ou étrangers, des laboratoires publics ou privés. 


\section{High-resolution stratigraphic forward modeling of a Quaternary}

\section{2 carbonate margin: controls and dynamic of the progradation}

3 J. Busson ${ }^{1,2,3}$, P. Joseph ${ }^{2}$, T.Mulder ${ }^{1}$, V. Teles ${ }^{2}$, J. Borgomano ${ }^{4}$, D. Granjeon ${ }^{2}$, C. Betzler ${ }^{5}$, E. $4 \quad$ Poli $^{3}$, M. Wunsch ${ }^{5}$

5 1. Université de Bordeaux, CNRS UMR5805 EPOC, allée Geoffroy St Hilaire, CS 50023, 33615

6 Pessac

7 Cedex, France

8 2. Direction Géosciences R16, IFP Energies Nouvelles, 1-4 avenue de Bois Préau, 92852 Rueil-

9 Malmaison Cedex - France

10 3. Projet "Carbonates", Exploration \& Production SCR/RD, Total S.A., CSTJF, Avenue Larribau, 1164000 Pau, France

12 4. Aix-Marseille Université, CNRS UMR7330 CEREGE, 3, Place Victor Hugo, 13331 Marseille Cedex 3, France

5. Institut für Geologie, Universität Hamburg, Bundesstr. 55, 20146 Hamburg, Germany

Corresponding author : Jean Busson ; jean.busson@u-bordeaux.fr

The relationships between the margin sedimentary regime and the platform progradation are studied using forward stratigraphic numerical simulations on the Leeward (Western) prograding margin of the Great Bahama Bank (GBB) during the Quaternary (1.7-0 Ma). The corresponding sedimentary regime in the slope and the platform is well known from the ODP leg 166 and Bahamas Drilling Project wells located along the "Western line" seismic transect. However the sedimentary regime on the margin is not well established: the coral reefal margin observed before between 1.7 and $0.8 \mathrm{Ma}$ in the well Clino is not active anymore at presentday, and the Holocene sedimentary regime is geometrically unable to account alone for the progradation. This study is based on three 2D high-resolution forward stratigraphic numerical 
modeling experiments with the software DionisosFlow that include the platform, margin and slope domains on the "Western Line Section" in the same sedimentary models. The results are compared to the six sedimentary cores and to the present day bathymetry in order to identify the more realistic scenario. The three experiments test different models of carbonate sediment production and transport. Experiment 1 shows that the highstand shedding of the fine-grained uncemented platform production is unable to reproduce the progradation and the present-day profile. Experiment 2 and 3 incorporate cemented facies in the margin, with the best results obtained with the cemented marginal wedges produced in Experiment 2 during platform emersion. From these results a high-resolution interpretation of the margin seismic section is proposed. This study shows that the platform progradation can be decoupled from the highstand shedding of the fine-grained platform production. It is dependent on the accumulation in front of the steep margin of coarse or cemented material. Before $0.8 \mathrm{Ma}$ this corresponds to the coral reef identified in Clino. The transition after 0.45 Ma to 100-kyr large eustatic cycles with total platform flooding created two distinct marginal regimes: (1) during platform flooding aggrading accumulation of non-skeletal sands, and (2) during platform emersion prograding cemented marginal wedges produced in-situ.

\section{KEYWORDS}

Bahamas; Forward Stratigraphic modeling; Carbonate slope; Platform Progradation; Lowstand wedges; Cemented margin

\section{Introduction}

\section{$47 \quad 1.1$ High-resolution stratigraphic study of a progradational margin}

Carbonate sedimentary systems are a major component of the rock record of sedimentary basins, and a major reservoir of geological resources (Schlager, 2005). The margin area is the transition domain from the shallow marine carbonate factory to the slope where sediments 
al., 2010; Reijmer et al., 2015). The sedimentary processes and physiography of the margin controls the stratigraphic evolution of the shallow platform and the sediment export mechanisms towards the slope (Eberli and Ginsburg, 1987; Playton et al., 2010). The evolution of the margin is influenced both by external factors, such as hydrodynamic conditions and tectonics, and internal ones, especially the variety of carbonate producers and the mechanical properties of the accumulated production (Playton et al., 2010).

Forward stratigraphic models such as the DionisosFlow software (Granjeon and Joseph, 1999; Granjeon, 2014) are a reliable tool to reconstruct the facies and geometry of a carbonate sedimentary system through time (Warrlich et al., 2008; Montaggioni et al., 2015; Berra et al., 2016; Lanteaume et al., 2018). This high-resolution stratigraphic model realizes a reliable process-based interpolation of the available geological data. They are used to constrain the geological parameters governing the modelled sedimentary processes (Aurell et al., 1998; Seard et al., 2013; Montaggioni et al., 2015; Kolodka et al., 2016)

This study focuses on the "Western Line" transect of the Great Bahama Bank (GBB) for the time interval 1.7 Ma to present day (Fig. 1A and 1B). Different scenarios defined by various carbonate producers and sediment properties are tested under well-constrained external controls. Different margin architectures are then generated and compared to the observations for the most recent deposits (Wilber et al., 1990; Eberli et al., 2004)and to the core sections on the slope and platform (Wilber et al., 1990; Eberli et al., 1997; Ginsburg et al., 2001; Eberli et al., 2004). These results give 1) insights on the internal and external controls of the margin geometry and evolution, and 2) their influences on the stratigraphic evolution of the whole transect. These modeling results provide conceptual insights for the sequential evolution of a leeward carbonate margin. 


\subsection{Bahamas case study: State of the art}

The Bahamas Archipelago is one of the most studied present-day analogues for ancient tropical carbonate systems (Fig. 1A). It has yielded major contributions on the understanding of carbonate systems (Schlager and Ginsburg, 1981; Mullins and Cook, 1986; Grammer and Ginsburg, 1992; Schlager et al., 1994; Eberli et al., 2004; Betzler et al., 2014; Reijmer et al., 2015). The low-angle leeward western slope of the GBB shows a remarkable progradation of $\sim 15 \mathrm{~km}$ into the Strait of Florida during the late Miocene (Eberli and Ginsburg, 1987; Eberli et al., 1997) (Fig. 1B, Fig. 2). The platform and slope architectures are well described on the 2D section known as the "Western line" defined by a continuous seismic platform-to-basin profile (Eberli and Ginsburg, 1987) (Fig. 1B). Six research wells were core-drilled on this transect during the Bahamas Drilling Project (BDP) (Ginsburg, 2001) on the platform, and during the ODP leg 166 (Eberli et al., 1997a) on the slope. The platform margin however has not been drilled for the Quaternary deposits younger than 1.7 Ma. The recent sedimentary processes on the slope and the platform have been well established (Mulder et al., 2012; Chabaud et al., 2016; Principaud et al., 2016; Harris et al., 2015; Wunsch et al., 2017; Schnyder et al., 2018). However, the margin sedimentary regime is described with good confidence only for the Holocene deposits by Wilber et al. (1990).

\subsubsection{Quaternary evolution of the Western margin}

The post-Cretaceous evolution of the "Western Line" transect is well constrained by the identification of $3^{\text {rd }}$ order sequences named $a$ to $r$ from the more recent to the oldest one (Betzler et al., 1999; Eberli et al., 2002; 2004; Principaud et al., 2016; Wunsch et al., 2018) (Fig. 2).

During sequence $d$ (2.6-1.7 Ma) the non-skeletal grains become abundant on the platform with coral reefs in well Unda (Budd and Manfrino, 2001). The platform margin progrades with 
the deposition of a thick regressive package but it is of reduced thickness on the slope. (Eberli et al., 1997b; Kenter et al., 2001; Principaud et al., 2016).

Sequence $c(1.7$ to $0.33 \mathrm{Ma})$ corresponds to another significant progradation pulse of the platform along with a transition from a ramp-like profile to a steeper platform margin profile (Eberli et al., 1997b; Betzler et al., 1999; Principaud et al., 2016). Coevally the carbonate production along the transect becomes almost entirely non-skeletal and peloid-dominated (Eberli, 2000; Kenter et al., 2001; Manfrino and Ginsburg, 2001). These evolutions can be related to a regional pattern of coral reefs decline and extinction during the Pleistocene, culminating between $1.0 \mathrm{Ma}$ and $0.8 \mathrm{Ma}$ (Reijmer et al., 2002).

The interval 1.7 to $0.8 \mathrm{Ma}$ is expressed by an subaerial exposure hiatus in well Unda and the progradation of a coral reefal margin in well Clino, with an evolution from reefal to reef crest and platform environment. After $0.8 \mathrm{Ma}$, the deposits in BDP wells Unda and Clino indicates mostly platform top and platform margin environments, respectively (Budd and Manfrino, 2001; Manfrino and Ginsburg, 2001) (Fig. 2, Fig. 4). On the slope, sequence $c$ to $a$ are dominated by the accumulation of periplatform-ooze wedges exported from the platform during the highstand flooding periods (Eberli et al., 1997a). These packages form periplatform drift wedges (Betzler, et al., 2014) under the action of the Florida Current (Principaud et al., 2016; Wunsch et al., 2018). They are separated by condensed cemented intervals related to the platform emersion during glacial lowstands (Eberli et al., 1997a; Eberli, 2000; Rendle and Reijmer, 2002) (Fig. 4).

\subsubsection{Recent margin evolution and sedimentary processes}

For the Holocene highstand, at the top of the Western Line sectionthe edge of the bank is gently sloping with a $3-10^{\circ}$ slope towards a slope break at 55-60 m of water depth (Wilber et al., 1990; Ginsburg et al., 2001). The platform edge shows a $10-30 \mathrm{~m}$ thick accumulation of Holocene fine to medium non-skeletal sands (Fig. 3A). A lithified marginal escarpment marks an abrupt increase in slope reaching more than $30^{\circ}$ down to a depth of $140-180 \mathrm{~m}$. Direct 
sampling of lithified samples a few meters inside the "escarpment wall" have also yielded

127 Holocene ages (G. Eberli, pers. comm.). At the bottom of the escarpment, a plunge-pool and related slope-break deposits result from the hydraulic jump of density cascading currents (Wilson and Roberts, 1992; Wilber et al., 1990; Wunsch et al., 2016; Schnyder et al., 2018).

Downslope the Holocene deposits form a 10 -to $60 \mathrm{~m}$ thick wedge of muddy periplatform oozeln the profiles of Wilber et al. (1990) the Holocene wedge clearly onlaps on Pleistocene surface of the plunge pool (Fig. 3A). The Holocene platform edge and thin wall deposits also appear to downlap this same surface in the lower part of the wall. Holocene sediment accretion in front of the escarpment seems severely limited by the strong activity of the downslope currents. Laterally along the GBB Western margin this profile vary with a more or less developed slope wedge (Wilber et al., 1990; Principaud et al., 2016).

137 If one takes a conceptual look at the architecture resulting from the repetitive stacking Highstand sediments accumulation at the margin identical to the observed Holocene package (Fig. 3A), it shows an aggrading trend for the platform margin (Fig. 3B). The construction of any prograding trend would have required additional sedimentary accumulation in front of and at the toe of the wall (Fig. 3C). So when considering the margin progradation from $0.8 \mathrm{Ma}$ to the Holocene, other types of margin geometries than the observed Holocene geometry would have to come into play at some points. The well-established "highstand shedding" regime of the Western line transect (Schlager et al., 1994; Eberli, 2000; Eberli et al., 2004) is not associated with a progradational geometry for the Holocene highstand on this section.

\subsection{Objectives of the paper}

We present here a stratigraphic forward numerical investigation of the evolution of the Western GBB margin during the $1.7-0 \mathrm{Ma}$ interval (Fig. 2). During this interval, the sedimentation on the margin is only known by the 1.7-0.8 Macoral reef found in Clino (Fig. 4), and the present-day regime of the Holocene margin (Fig. 3A). Our objective is to investigate 
151 the stratigraphic architecture in the uncertain domain between these two records with the 152 following questions in mind:

1) How has the margin evolved between 1.7 and $0 \mathrm{Ma}$ ?

2) What is the relationship between the margin geometries and the depositional model? Which external and internal controls can be identified?

3) How does the architecture of the margin influence the progradation of the platform?

To apply a process-based modelling approach, it is necessary to use a unequivocal and consistent stratigraphic framework with time-lines that will be considered as stratigraphic markers across the whole well transect. Numerous chronostratigraphic studies have been published on this transect (Eberli et al., 1997b, McNeill et al., 2001; Eberli et al., 2002; Rendle and Reijmer, 2002; Principaud et al., 2016; Wunsch et al., 2018; see Table 1). They present some discrepancies and uncertainties: Eberli et al. (2002) estimate an average error of 0.38 Myr in their estimation of sequence $c, b$ and $a$ in the ODP wells, and on the platform wells only the 1.7 Ma and 0.8 Ma magnetostratigraphic markers can be considered as certain (McNeill et al., 2001). Choices and hypotheses made in this paper are not a new chronostratigraphic model for the "Western line" transect, but only a consistent synthesis of the published data. The results of the numerical experiments are used in the discussion to propose a highresolution interpretation of the seismic record at the platform margin ((Eberli and Ginsburg, 1987; Principaud et al., 2016; Wunsch et al., 2018).

\section{Data and Methods}

\subsection{Well Data}

172 The ODP leg 166 wells 1005, 1004, 1003 and 1007 were drilled on the slope. They were logged 173 with a full set of wireline tools and a checkshot survey was realized for wells 1003, 1005 and 1741007 (Eberli et al., 1997a). 
175 The two wells Clino and Undawere drilled on the platform as part of the Bahamas Drilling 176 Project (BDP) campaign (Ginsburg, 2001). Both are located on a very shallow platform (about 7 $177 \mathrm{~m}$ water depth), the well Unda is located $8.5 \mathrm{~km}$ inward of the well Clino along the "Western 178 Line » profile (Fig. 1A and Fig. 2. Both holes were logged with a standard suite of wireline tools 179 and a continuous vertical seismic profile (VSP) was shot (Ginsburg et al., 2001).

\subsubsection{Well Chronostratigraphy}

The chronostratigraphy on the ODP leg 166 slope wellsis first based on the planktonic foraminifer and nannofossil biostratigraphic framework built for the Leg 166 initial report (Eberli et al., 1997a). Another dating approach was conducted by Rendle and Reijmer (2002) on the wells 1007,1003 and 1005 , based primarily on $\delta^{18} \mathrm{O}$ isotopes, grain size and X-Ray Diffraction (XRD) analyses, U/Th dating and nannofossils bio-events to establish a highresolution stratigraphy of the Quaternary deposits (Rendle et al., 2000). Wunsch et al. (2018) proposed another high-resolution stratigraphy based on the distal ODP 166 sites 1008 and 1006. They are not located in our zone of interest and record a different sedimentary regime dominated by the Florida current (Rendle and Reijmer, 2002). As these are globally undisturbed sections, compared to the slope wells these records present higher confidence for the local stratigraphy, but higher uncertainity in the correlation with sections on the slope. For the BDP wells an age model has been established as well using foraminifera, nannofossils, strontium isotope stratigraphy and magnetostratigraphy (Mc Neill et al., 2001). The chronostratigraphic correlation of the platform (BDP) and the slope (ODP 166 wells) has not been established and published yet. A synthesis of the available literature led us to establish a consistent age/depth correlation for all the wells, based only on geological reasoning in case of contradictory results (Table 1). We did not endeavour to re-date the cored sections. This work was guided by the premise that exposure surfaces on the platform form time-lines corresponding to condensed and lithified layers on the slope (Eberli and Ginsburg, 1987; Eberli et al., 2002: Wunsch et al., 2016). For the slope wells we considered the 
correlation of early lithified layers and peaks of High Magnesium Calcite (HMC) (Eberli et al., 1997a; Rendle and Reijmer, 2002).

In this synthesis we identify and correlate the seismic sequence boundaries (SSB) A, B and C defined by Eberli et al. (1997a, 1997b and 2002) (Table 1, Fig. 4).

With an age of 1.7 Ma SSB C was correlated with the Top Olduvai datum in the BDP Well Unda and Clino (Manfrino and Ginsburg, 2001). This choice is consistent with the interpretation of SSB C as a major downward shift of the regressive margin (Eberli et al.,1997b; ; Manfrino and Ginsburg, 2001; Principaud et al., 2016).

SSB B was identified on the slope wells by Rendle and Reijmer (2002) with the condensed surface of MIS (Marine Isotope Stage) 10 at 0.37 Ma (Lisiecki and Raymo, 2005).On the platform SSB B was identified as an exposure surface at the top of a thick transgressive reefal unit in BDP well Clino (40 - $28 \mathrm{mbsf}$ ) and the corresponding deep lagoonal unit in well Unda (38 - 27 mbsf) (Manfrino and Ginsburg, 2001). We assume it to be the backstepping record of the highly transgressive MIS 11 highstand (Lisiecki and Raymo, 2005; Miller et al., 2011).

SSB A is defined in the ODP slope wells as the base of the Holocene deposits (Eberli et al., 1997a, 2002; Rendle and Reijmer, 2002;).. The corresponding exposure surface has not been recovered in Clino and Unda, but has been identified with the bottom of the Holocene unconsolidated sediments (Manfrino and Ginsburg, 2001; McNeill et al., 2001).

Three additional stratigraphic markers have been tentatively identified in the $1.7-0 \mathrm{Ma}$ interval in order to increase the stratigraphic constrains for the comparison of simulations with well sections.

Marker t20, corresponds to the top of MIS 20 (0.79 Ma) (Lisiecki and Raymo, 2005). It is identified in well 1003 by Rendle and Reijmer (2002) and is coeval with the Brunhes/Matuyama magnetostratigraphic transition,identified in Clino and Unda by Manfrino 

and Ginsburg, (2001). This surface was correlated in the ODP slope wells with the first notable peak of HMC composition and a remarkable positive Vp anomaly (Table 1, Fig.4).

229 The second stratigraphic marker, t12, corresponds to the top of MIS 12 (0.42 Ma), identified in ODP well 1005 and 1003 (Rendle and Reijmer, 2002). It can be correlated in wells 1004 with an abrupt decrease in Low Magnesium Calcite (LMC) concentration (Fig. 4). In the BDP wells it was correlated with the base of the transgressive reef/lagoon unit (Manfrino and Ginsburg, 2001) interpreted to correspond to MIS 11 (Table 1, Fig. 4). Raymo, 2005). It is identified in ODP wells 1005 and 1004 as the top of the penultimate condensed level (Fig. 4), in good agreement with ODP 166 U/Th dating (Henderson et al., 2000). It is absent in well 1003 that exhibits a major hiatus between t10 and the Holocene (Rendle and Reijmer, 2002). In BDP wells Clino and Unda, it was identified as the first transgressive lag cored (Manfrino and Ginsburg, 2001) (Table1, Fig.4).

\subsubsection{Core lithofacies analysis}

A synthetic lithofacies model with five facies was elaborated from the published core descriptions (Eberli et al., 1997a; Kenter et al., 2001; Manfrino and Ginsburg, 2001; Rendle and Reijmer, 2002). The lithofacies are designated by the Well Facies code (WF) A to G (Table 2). They are identified by a depositional environment, range of Dunham sedimentary fabric and dominant cementation state and mineralogical composition.

The highstand carbonate sedimentation on the platform is dominantly aragonitic with a finegrained (Silt and Clay size) and peloidal assemblage (Eberli et al., 1997a; Chabaud et al., 2016; Harris et al., 2015). It originates mostly from aragonitic green algae and seagrass production, especially Halimeda sp. and Thalassia sp., and whiting events (Eberli et al., 1997a; Manfrino and Ginsburg, 2001; Chabaud et al., 2015; Harris et al., 2015;). 
251 WF $A$ is the periplatform ooze slope facies corresponding to the off-bank export of the

252 highstand platform production (Wilson and Roberts, 1992; Schlager et al., 1994; Eberli, 2000;;

253 Wunsch et al., 2018).

254 WF B corresponds to the condensed deposits associated with glacial sea-level lowstands 255 (Eberli et al., 1997 a; Eberli, 2000; Chabaud et al., 2016; Wunsch et al., 2017).. WF B is 256 aragonite-poor due to 1) the dissolution of aragonite followed by the precipitation of an High257 Magnesium Calcitic micro-sparitic cement (Schlager and James, 1978; Mullins et al., 1980; 258 Mullins et al., 1985;; Munnecke et al., 1997; Eberli, 2000; Rendle et al., 2000; Melim et al., 2002;) and 2) a higher relative input of calcitic pelagic tests during lowstands (Eberli et al., 1997a; Eberli, 2000; Chabaud et al., 2016). WF B is clearly identifiable with 1) the marked decrease in aragonite composition in the XRD mineralogical log and 2) P-positive Wave velocity anomaly in relation with 3) early lithification state (Eberli et al., 1997a). Several lower slope sub-facies are incorporated into WF A for synthetic considerations(Eberli et al., 1997a).

WF C corresponds to a variety of coral reef facies (Kenter et al., 2001; Manfrino and Ginsburg, 2001). WF D is interpreted by Manfrino and Ginsburg, (2001) as high-energy sandy deposits of inner platform beach and shoals. It as the last member of shallowing upward sequences (Aurell et al., 1995)

\subsection{Seismic data}

The seismic interpretation has been performed on a dataset composed of three different acquisitions on the "Western Line" transect (Fig. 2). 1-The original "Western Line" profile acquired in the 1980's. Resolution in this seismic data is around $30 \mathrm{~m}$ in the upper part studied here It is presented in the original undersampled publication format with one trace out of seven (Eberli and Ginsburg, 1987). 2- Wunsch et al. (2018) (Fig. 9 A) have published the reprocessed version of this seismic, presented also in Eberli et al. (2004) (Fig. 16, from the platform edge and margin between well 
2771005 and well Clino for 0 to 700 ms TWTT). . As is clearly visible in Eberli et al. (2004) due to

278 the very high impedance contrasts on the shallow platform, the seismic data have been cut at

$279 \sim 0.08 \mathrm{~ms}$ TWTT. It gives the outer platform a flat top appearance, whereas it is indeed sloping 280 from $7.6 \mathrm{~m}$ water depth in Clino (Manfrino and Ginsburg, 2001) to $60 \mathrm{~m}$ at the platform edge 281 (Wilber et al., 1990)(Fig. 11A).

282 3- Slope seismic data collected during the seismic survey of Leg 1 of the Carambar cruise (Mulder et al., 2012). have a vertical resolution of $2 \mathrm{~m}$ and are relevant down to approximately 1s TWTT (Principaud et al., 2016). A small displayed section in Figure 11 is part of the ODP 166 high-resolution dataset studied by Anselmetti et al. (2000).

\subsubsection{Well tie}

Well-tie data were published for the ODP well sites (Eberli et al., 1997a; Anselmetti et al., 2000; Eberli et al., 2002; Wunsch et al., 2018) providing with time-depth points for the SSB A, B and $\mathrm{C}$ (Fig. 2B ). The preservation of reflector continuity for SSB B on the slope gave us a slightly shallower value at well 1005 of 80 ms TWTT versus 100 ms. Eberli et al. (2001) published also well tie data for the platform wells with the reprocessed seismic. We use these values, though for SSB A they fall above the cut at $0.08 \mathrm{~s}$. The time geometry of SSB A and the seafloor was reconstructed based on these points, the reflectors visible at the platform edge and similar to the geometry of Wilber et al., 1990, and the knowledge of the sea-floor depth at the platform edge (55-60 m, Wilber et al., 1990) and at Clino and Unda (7.6 and $6.7 \mathrm{~m}$ respectively, Manfrino and Ginsburg, 2001) (Fig. 11B).

\subsection{Stratigraphic forward modeling}

\subsubsection{Model outlines and strategy}

299 The numerical forward stratigraphic DionisosFlow model (Granjeon and Joseph, 1999) was 300 designed to investigate the 3D development of siliciclastic and carbonate sedimentary systems at the basin scale. It has been used for smaller scale clastic or carbonate systems (Rabineau et 

architectures below the fifth order time-scale resolution. The model offers the possibility to test the impact of a conceptual depositional model on the internal stacking pattern and stratigraphic evolution of the resulting sedimentary accumulation (Warrlich et al., 2008; Montaggioni et al., 2015; Lanteaume et al., 2018). In this study the choice of the processes and the values of the parameters are based on the available geological constraints and fitted through a trial and error process. The quality of experiment is determined by the fit of the simulated stratigraphic markers position against their core interpretation and the valid geometry of the reconstructed present-day margin profile.

Three modelling experiments are tested on DionisosFlow (Fig. 5). under a given eustatic history.

We used here a $42 \mathrm{~km}$ long 2D model, with a grid resolution of $50 \mathrm{~m}$. Time is discretized into 340 time-steps of $5 \mathrm{kyr}$ from 1.7 to $0 \mathrm{Ma}$ BP. This pseudo 2D section represents the "Western line" transect projected in a direction orthogonal to the slope (Fig. 1B). It comprises $12 \mathrm{~km}$ of platform domain, and $30 \mathrm{~km}$ of slope domain. Due to the limited modeling of the contour current activity in a 2D section, the displayed zone of interest is limited to the slope domain and stops downward of well 1007 (Fig. 1B), with $12 \mathrm{~km}$ of platform domain and $9 \mathrm{~km}$ of slope 
328 (21 km in total). The ODP and BDP wells were also projected under a cylindricity hypothesis on

329 this modelled section (Betzler et al., 1999).

In DionisosFlow carbonate production is defined through time by the definition of a source function. It describes $\mathrm{CaCO}_{3}$ production rate according to water depth. In this study it is tied to a type of carbonate sediment material that can be more or less easily traced back to a mix of biogenic sources. Depending on the simulated sediment, this sediment source function can integrate already a certain range of mixing, degradation and transport processes in the simulated "production » process. In that case it is would be more aptly described as an "accumulation" rate. The production rates are defined in order to fit, insofar as possible, the observed architecture. They are heavily dependent on the geometry and transport efficiency of the simulation.

The transport processes are modelled in DionisosFlow by a non-linear diffusion law approximation ( Granjeon, 2014). Several diffusion coefficients are attributed to each sediment class in order to model the slope-driven transport and the wave-driven transport. The slopedriven transport expresses the sediment flux Qs=K*S where $S$ is the local slope, and $K$ the diffusion coefficient in $\mathrm{km}^{2} / \mathrm{kyr}$. In the western GBB sedimentary system the major part of the transport of the fine-grained production on the platform towards the slope is due to an advection process: density-cascading of sediment-laden water from the platform (Wilson and Roberts, 1992; Eberli, 2000; Wunsch et al., 2016 ). This remobilization of sediment on the platform was simulated in DionisosFlow using a 1D wave model defined with a wave base action depth at $20 \mathrm{~m}$ (fair-weather waves). The bathymetry-dependent wave energy function allows the remobilization of the sediment according to the local wave energy. Sediment transport on the platform is actually driven by the wind and the shallow tidal currents (Harris et al., 2015). This wave-driven diffusion function is used as a diffusion boost to account for 
these complex shallow transport processes on the flat platform. The reworked sediment is then transported according to the local slope under the rules of gravity-driven diffusion.

\subsection{Simulations parameters}

\subsubsection{External controls}

A constant and uniform subsidence rate of $34.1 \mathrm{~m} / \mathrm{Myr}$ was assumed as there is no evidence of vertical relative sediment displacement along the transect (Eberli and Ginsburg, 1987; Eberli et al., 2004; Principaud et al., 2016; Wunsch et al., 2018). This value is calibrated by the reconstitution of the correct present-day position for SSB C line and the $56 \mathrm{~m}$ thick accumulation observed at well Unda. The eustasy parameter was derived from the curve of Miller et al. (2011) resampled at $5 \mathrm{kyr}$ resolution. In order to better constrain the real accommodation space and sedimentation rate, we also simulated the mechanical compaction. The definition of the initial basement topography is a key assumption for the whole simulation (Montaggioni et al., 2015; Lanteaume et al., 2018). We considered the depth of the SSB C in the six wells of the section to draw a 1.7 Ma topographic profile consistent with the seismic interpretation. The initial sea-level position at 1.7 Ma was derived from the location of the first onlap in the seismic interpretation. The platform level is thus set at $40 \mathrm{~m}$ above sea-level at 1.7 Ma.

The Santaren Current is considered as a major external control, limiting sediment accumulation at the toe-of-slope (Betzler et al., 1999; Rendle and Reijmer, 2002; Betzler et al., 2014; Principaud et al., 2016; Wunsch et al., 2018). It was integrated in the pseudo-2D DionisosFLow with an open boundary condition on the basin section westward of well 1007. A constant northward discharge of $0.01 \mathrm{~km}^{3} /$ Myr of fine-grained sediment is applied. It prevents deposition in the basin fixes the toe of the progradation at $\sim 10 \mathrm{~km}$ from the platform break. In the model the contour current effect was activated after $0.8 \mathrm{Ma}$, though it has likely been active since the Pliocene (Rendle and Reijmer, 2002; Principaud et al., 2016; Wunsch et al., 

deposits between $1.7 \mathrm{Ma}$ and $0.8 \mathrm{Ma}$, and only $12 \mathrm{~m}$ after.

381

382

\subsubsection{Definition of carbonate producers}

Three different carbonate producers are considered in our experiments for the Quaternary interval (1.7 - $0 \mathrm{Ma})$. They are simulated by different bathymetry-dependent source functions (Fig. 6), and different high-diffusion or low-diffusion gravity driven transport laws, determining respectively low or high slope angle of accumulation (Granjeon, 2014). Following the analysis of Kenter (1990) the slope of accumulation of the carbonate production is directly related to its dominant sediment fabric.

As explained in section 4.1 the value of the wave transport coefficients for the same facies can vary between different experiments in order to keep a comparable off-bank sediment flux (Table 3). The contrast in wave-driven diffusion coefficients expresses the easy mobilization of fine-grain uncemented sediment in respect to the cemented material accumulated in situ.

The contrast between the high-diffusion and low-diffusion facies is always preserved. Low slope-driven diffusion coefficients (Table 3) expresses the ability of cemented, bioconstructed/binded or coarse grained facies to build stable accumulations with steep slopes (Kenter, 1990; Playton et al., 2010).

The first producer, designed as "aragonite ooze", corresponds to the fine-grained aragonite ooze produced on the platform. It has a very high gravity diffusion coefficient, constrained by the very low slope angle of periplatform ooze accumulation (Kenter, 1990; Playton et al., 2010) (Table 3). The ooze deposits cannot form any relief on the platform nor accumulate on the steep margin (Fig. 5).It is easily remobilized by the hydrodynamic currents on the platform and exported to the slope (Fig . 5). It is simulated with a high value of wave driven-diffusion coefficient (Table 3). 
406 Two other producers were defined to account for the marginal production and accumulation.

407 Both are cemented low-diffusion sediment accumulating in steep marginal configurations

408 (Kenter, 1990; Grammer and Ginsburg, 2012; Betzler et al., 2016). The low diffusion value

409 limits also their transport in the low-angle slope domains. They have a low wave-driven

410 coefficient as they accumulate in-situ.

411 The first one is named as "reef \& cemented talus" (RCT). It aims at simulating the lowstand

412 coarse cemented wedge described by Grammer and Ginsburg (1992), supplied in particular by

413 a fringing reef development.

414 The second one is named as "coarse \& cemented platform edge" (CCPE). It aims at simulating

415 the sandy and cemented accumulation described at the platform edge by Wilber et al. (1990).

416 They are transported by shallow platform currents to this outer and deeper platform edge

417 depocenter at water depth extending from 10 to $60 \mathrm{~m}$ (Wilber et al., 1990). As explained in

418 section 4.1 the crudel model of hydrodynamism on the platform in these simulations is unable

419 to simulate consistently this transport toward the platform edge where the sediment is

420 accumulated and cemented. As a consequence the CCPE material is directly simulated as a

421 cemented low-diffusion sediment, and its source function is actually an accumulation curve in

422 the platform edge depocenter. Since it is composed of non-skeletal grains (ooids, pelletoids

423 and grapestone) produced on the inner platform (Wilber et al., 1990; Harris et al., 2015) the

424 CCPE producer is active in the simulation during platform flooding only.

A mechanical compaction curve was associated to each producer. For the " aragonite ooze » it

was designed from experimental results of five oedometers tests on periplatform ooze samples from sediment cores of the Little Bahama Bank (LBB) northern slope, and three oedometer tests on periplatform ooze of the same slope published in Lavoie et al. (1988). The proposed curve is consistent with the porosity trend of the four ODP Leg 166 wells on the 
431 slope. For the RCM and CCPE material, the "coarse" compaction curve of Caspard et al (2004)

432 calibrated for the platform margin of the "Western Line" section was used.

\section{$433 \quad$ 2.4.3 Production laws}

434 The production of the "aragonite ooze" facies occurs during whitings event and with the degradation of green algae and seagrasses (Halimeda sp., Thalassia sp.) on the shallow platform (0-10 m water depth) (Schlager and Ginsburg, 1981; Manfrino and Ginsburg, 2001; Harris et al., 2015). It decreases progressively with the light intensity and stops at $50 \mathrm{~m}$ water depth corresponding to the base of the present-day photic zone in Bahamas (Schlager et al., 2005) (Fig. 6).

The production function for the RCT facies is defined with maximum production at $10 \mathrm{~m}$ water depth as observed for corals (Pomar and Hacq, 2016) (Fig. 6). This production is also restricted to the high wave energy domain above $80 \mathrm{~W} / \mathrm{m}^{2}$ in order to prevent it reaching in the shallow platform interior. The sustained production rate between 30 and $50 \mathrm{~m}$ allows to account for an oligotrophic component (Betzler et al., 2016) and the gravity driven accumulation of erosional lithoclasts (Grammer and Ginsburg, 1992).

The production of the CCPE facies is defined with a similar shape but it creates slighty deeper accumulation down to the mesophotic zone (Wilber, et al., 1990) (Fig. 6). The values of the production rate vary during the simulation (Fig. 6). These variations come mostly from the trial-and-errors calibration of the best fit for all the three experiments. They also account for the general warming that followed the end of the Mid-Pleistocene Transition and the Mid-Bruhnes event ( 0.45 Ma) (Reijmer et al., 2002; Wunsch et al., 2018). The increasing trend for the "aragonite ooze" and "CCPE" facies production corresponds to the increase in the flooded surface of the platform during the highstands (Kievmann, 1998). The very high values of the "aragonite ooze" production for Experiment 2 are explained in section 4.4. 


\subsubsection{Definition of resulting lithofacies}

457 The definition of five simulated lithofacies, based on the sediment composition and sedimentation rate, allows to highlight and understand the interplay between the muddy aragonitic highstand sediments in the platform and slope and the coarser or more cemented margin sediments (Table 4). The two slope facies (below $150 \mathrm{~m}$ ) "Periplatform ooze" and "cemented ooze" are distinguished only by a sedimentation rate threshold of $1000 \mathrm{~m} /$ Myr. The diagenetic signal of early cementation is simulated here (Fig. 7, Fig. 8) using the sedimentation rate as a proxy.

\section{Results}

\subsection{Experiment 1: fine-grained uncemented margin}

Experiment 1 is constructed with reefal production between 1.7 and $0.8 \mathrm{Ma}$ only, leaving only the inner platform aragonite ooze production between 0.8 and the present (Fig. 6). The result shows a remarkable contrast between these two. During 1.7-1.4 Myr interval, the accumulation of mostly reefal production on the upper margin profile creates a lowstand wedge, both prograding downslope and onlapping upslope. It finally covers the whole platform domain during the 1.5-1.4 Ma transgression (Fig. 7A). During this period there is bypass on the

473 steep margin and reduced deposition in the slope. During the following 1.4-0.8 Ma interval the prograding/aggrading evolution of the margin evolves towards a more forced prograding pattern. Vertical accretion on the platform is much reduced, but becomes dominated by aragonite ooze production (Fig. 9A). Accumulation of reefal production at the front of the margin ensures the profile progradation as the slope accumulation is much reduced. accretionary slope profile with a constant gradient and a flat-top platform (Fig. 7A). 

deposition in the system and no effective progradation of the platform (Fig. 7C). This general modification is due to both the end of low-diffusion reefal production and the change of eustatic regime with lower maximum values and two marked falls at 0.6 and 0.42 Ma (MIS 16 and 12) that reduce the available accommodation space.

With the major transgression of MIS $11(0.42-0.37 \mathrm{Ma})$ the platform is flooded again allowing accumulation of aragonite mud on the platform and export downslope of a very large onlapping highstand wedge (in red on Fig.7A). The successive flooding of MIS $9(0.34-0.30$ $\mathrm{Ma})$ and $5(0.13-0.07 \mathrm{Ma})$ leaves no large accumulation on the platform, but two slope wedges that onlap progressively above the platform edge (Fig.7). This succession creates an accretionary prograding margin and a smooth slope profile with a very open platform margin (Fig.7 C). Consequently the Holocene leaves a continuous prograding tract of mud, without the onlap of a distinct slope wedge (Fig.7 A).

Experiment 1 results partially reproduce the platform accumulation in wells Clino and Unda. On the slope it captures the general increase of sedimentation rates after $0.8 \mathrm{Ma}$ and the alternation of thick interglacial highstand packages with condensed lowstand surfaces. However it oversestimates the sediment thickness in the slope wells after $0.42 \mathrm{Ma}$, and underestimates it before $0.8 \mathrm{Ma}$ (Fig. 9A). There is construction of a progradational margin but the progradation is not developed enough (Fig. 7C). Most importantly, the steepening trend and the present-day profile are not reproduced (Fig. 7A). A constant smooth slope is instead realized as only one diffusive material is accumulated. Any increase in production and export would lead to larger progradation but also greater overestimation of the slope accumulation. A decrease would result in loss of progradation or even no margin deposition after $0.8 \mathrm{Ma}$, though the thickness at the slope well would be more 
correct. The constant slope depositional profile is unable to reproduce the steep margin and low angle slope transect evolution.

This experiment of highstand progradation of uncemented fine-grained sediment tracts is not consistent with the progradation of the observed section. Another depositional model must be considered for the Quaternary leeward slope.

\subsection{Experiment 2: Cemented margin}

For the 1.7-0.8 Ma period, experiments 1 and 2 are fairly identical, except for the thickness of the downslope aragonite mud deposits (Fig. 9B). This might be a consequence of the increased wave diffusion coefficient (export efficiency) in experiment 2 (Table 3).

However, after 0.8 Ma, the depositional architecture is quite different: during the 0.8-0.4 Myr interval, deposition of cemented facies occur on the margin, maintaining the steepening trend under a forced regression regime (Fig. 7A and B). Export of aragonite mud on the slope also occurs (Fig. 9B). Similarly, the MIS 11 flooding after $0.42 \mathrm{Ma}$ leads to aragonite mud accumulation on the platform and the slope (Fig. 8). However the onlapping slope wedge is in a lower position and of smaller volume than in experiment 1 . There is aggradation of RCT material in the margin, maintaining the steep profile. RCT material also backsteps on the platform (Fig. 7B). This can be related to the reefal accumulation observed in well Clino between 48 and $35 \mathrm{mbsl}$ (Fig. 9B) and interpreted by Manfrino and Ginsburg (2001) as a reefal backstep. Accumulation is relatively reduced during MIS $9(0.34-0.3 \mathrm{Ma})$ on the platform and the onlapping slope wedge. The MIS 8-6 (0.3 - 0.13 Ma) interval shows only accumulation of cemented material on the margin, forming a lowstand prograding wedge onlapping up to the platform edge and dowlapping down to the top of the slope (Fig. 7C). MIS 5 (0.13-0.07 Ma) repeats the depositional pattern of MIS $11(0.42-0.37 \mathrm{Ma})$ with a reduced thickness and no backstepping of the marginal cemented accumulation. The sea-level fall during MIS 2-4 (0.07$0.01 \mathrm{Ma}$ ) leads to the deposition of another lowstand marginal wedge of cemented material. It 
evolves into an aggrading margin with the Holocene transgression and the deposition of the

531 platform and onlapping slope highstand deposits (Fig. 7C).

532 This experiment reconstructs fairly well the steepening trend and the present-day geometry of 533 the profile (Fig. 7A). The well succession on the slope and platform is well reproduced, 534 especially in terms of the different sedimentary packages and the total thickness (Fig. 9B). 535 However the thicknesses of the highstand packages after $0.33 \mathrm{Ma}$ are always moderately 536 underestimated (Fig. 9B). The repartition of the two simulated facies is in good agreement 537 with the information from the wells. The highstand shedding pattern of off-bank mud export 538 into onlapping slope wedges is well reproduced in this experiment. The "Aragonite mud " is 539 accumulated on the inner platform and on the slope, in onlapping highstand wedges separated 540 by aragonite poor glacial layers. The cemented facies accumulates in the margin in two 541 positions. It creates lowstand marginal wedges during the platform emersion periods, 542 especially during the MIS $16(0.68-0.62 \mathrm{Ma})$ (, MIS $12(0.48-0.42 \mathrm{Ma})$, MIS 8-6 (0.3-0.13 $543 \mathrm{Ma})$ and MIS 4-2 (0.07-0.01 Ma) intervals. Its ability to accumulate at steep slopes allows to fill 544 part of the accommodation space available on the margin during these periods. The cemented 545 facies also aggrades at the platform edge during flooding periods, maintaining a steep margin 546 profile. However this affects the exact restitution of the platform depositional profile. Very 547 flat-top platform morphology are created, as early as $1.5 \mathrm{Ma}$, whereas the present-day profile 548 show a sloping geometry seaward of Clino and a more open margin (Fig. 7C). The RCT 549 accumulation at the margin creates an inconsistently steep and shallow geometry.

550 The accumulation of cemented facies in lowstand marginal wedges allows for steepening of 551 the profile. The and the progradation of the platform (Fig. 7C). The architecture obtained is 552 that of a composite prograding margin. This experiment 2 proposes a satisfying forward 553 reconstruction, but the exact nature and existence of the prograding cemented lowstand 554 wedges need to be assessed. 


\subsection{Experiment 3: Cemented margin during highstand only}

556 The results of experiment 3 stand in-between those of Experiment 1 and 2. Indeed it 557 comprises a cemented facies, as Experiment 2, but the production after $0.8 \mathrm{Ma}$ is nevertheless

558 limited to the highstand periods (Fig. 8). Before $0.8 \mathrm{Ma}$ the results are very similar to 559 Experiment 1, with the same deficit of export to the slope, probably related to the relatively 560 low value of the wave-diffusion coefficient (Fig. 9C and Table3). During the critical period 561 between 0.8 and $0.42 \mathrm{Ma}$ the production is limited to the margin area with the CCPE in a 562 forced regression configuration (Fig. 7A and B). The reality of non-skeletal carbonate 563 production for the CCPE accumulation during this period of very limited platform flooding is debatable. This is why reduced production values were attributed to this facies during this period (Fig. 6). After $0.42 \mathrm{Ma}$ the results for the slope domain are similar to the Experiment 1 , with very high sedimentation rates (Fig.8). The margin profile is however similar to Experiment 2, but with less progradation (Fig. 7C). In the absence of lowstand production the cemented margin is simply aggrading, as proposed in Figure 3B.

569 In this last experiment, the general architecture is well reconstructed, except in the slope

571 (excess of sediment) and in the reduced platform progradation. In contrast with experiment 1, 572 the simulated section in Clino is fairly correct (Fig. 9C). Indeed the platform profile is well573 reproduced in this scenario, with a steep margin escarpment but still a relatively convex and 574 open platform to margin transition (Fig. 7A). This is a good validation of the reproduction of 575 the Holocene platform edge depocenter described by Wilber et al. (1990). The accumulation of cemented material during highstand flooding periods allows building a steep leeward margin profile, but the major drawback of this simulation is the absence of progradation even with very high rates of export and sedimentation on the slope. In a transect dominated by leeward offbank transport and highstand shedding, the presence of the lowstand marginal wedges of experiment 2 still appear critical for the progradation of the platform. 


\subsection{Platform-to-basin Stratigraphic evolution}

582 The DionisosFlow simulations defines two major periods for the Quaternary interval. They are 583 separated by a transition interval between 0.8 and $0.4 \mathrm{Ma}$ that corresponds to the transition 584 from 41-kyr eustatic cycles to the 100-kyr eustatic cycles (Fig. 7D).

585 After the sea-level fall at 1.7 Ma, a well-developped coral reef progrades in the upper margin 586 (Budd and Manfrino, 2001). The progradation of the reef and lagoon unit is clearly reproduced 587 in all the Dionisosflow experiments. It is illustrated in well Clino by the vertical succession of 588 coral framestone, coral floatstone and lagoonal mud until 70 mbsf (Manfrino and Ginsburg, 2001) (Fig. 4 and Fig. 10). The Dionisos experiments correlate this growth episode with the 1.7-1.4 Ma time interval which corresponds to a general sea-level rise (Fig. 7D). Deposition in the slope is limited and seems to start after the more widespread flooding of the platform landward of well Unda after $1.5 \mathrm{Ma}$ (Fig. 8).

After the initial build-up of this aggrading/prograding reefal wedge at the margin, the simulated stratigraphy evolves towards a regressive pattern. Important changes take place during the normal to forced regressive interval (0.8 - $0.42 \mathrm{Ma})$ (Fig. 6) with very little accumulation on the platform (Fig. 7A). In Clino, a 10-m-thick lagoonal mud interval may indicate a significant flooding possibly related to the relative sea-level highstand of MIS 17 $(0.71-0.68 \mathrm{Ma})$ or MIS $19(0.79-0.76 \mathrm{Ma})$. Otherwise the lithologic records in wells Clino and Unda for this period show reduced accumulation, with four emersion surfaces in $20 \mathrm{~m}$ of stacked platform deposits (WF D and E) (Fig. 4). This corresponds to the globally low sea-level values of the eustatic curve.

602 . This eustatic evolution between 0.8 and $0.42 \mathrm{Ma}$ ensures that the sediment accumulation is limited to the margin domain (Fig. 8). The lower accumulation rates on the slope combined with the margin progradation lead a steepening of the profile.(Fig. 7A). 
$607(0.42-0.37 \mathrm{Ma})$ is the first flooding of the whole GBB platform (Aurell et al., 1995; Kievmann 608 et al., 1998). It is well expressed in the three simulations as well as in the platform wells (Fig. 609 9). On the platform, a retrograding transgressive package compound of interlayered coral 610 floastone and lagoonal mud correlates in experiment 2 with a major increase of "Aragonite 611 ooze" sediment (Fig. 7A and Fig. 9). The coeval sediment bypass in the marginal escarpement 612 and the thick onlapping deposit in the slope (53 $\mathrm{m}$ in well 1005) are well apparent in the three experiments (Fig. 7A). Flooding of the platform occurs during MIS 9 (0. $34-0.3 \mathrm{ma})$ and 5 (0.13

$614-0.07 \mathrm{Ma}$ ) (Aurell et al., 1995; Kievmann, 1998; Rendle and Reijmer, 2002) (Fig. 9). MIS 7 sealevel peak is distinctively lower (Lisiecki and Raymo, 2005; Miller et al., 2011) and might not have flooded the whole platform (Fig. 7D). Concerning the platform and margin, the detailed

617 identification in wells and seismic record of the highstand packages between SSB B and A is 618 relatively difficult (Eberli et al., 2013). Deposition during MIS 10-6 (0.37-0.13 Ma) appears 619 very limited in Clino and Unda, with mixed skeletal/non skeletal accumulation in the former 620 (Fig. 9). MIS $5(0.13-0.07 \mathrm{Ma})$ highstand is instead well-associated with platform deposits in both Unda and Clino.

622 A remarkable result of the Dionisos simulation is the simulation of the actual sedimentation rates on the section (Fig. 8). They can reach up to $8 \mathrm{~m} / \mathrm{kyr}$ during the MIS $11(0.42-0.37 \mathrm{Ma})$ transgression. Such high-values are driven by the very short duration of effective sedimentation period and are similar to those of Wilber et al. (1990) for the Holocene. For instance the Holocene slope wedge with sedimentation rates above $5 \mathrm{~m} / \mathrm{kyr}$ is mostly deposited after 5 kyr B.P., when the platform flooding is effective, and not since the beginning of MIS 1 (14 kyr BP) (Lisiecki and Raymo, 2005; Montaggioni et al., 2015; Chabaud et al., 2016). 


\subsection{Numerical experiments limitations}

631 Several limitations exist in the DionisosFlow numerical simulations, affecting the validity of the

632 detailed simulated architectures. They do not suppress however the consequences of the initial 633 design of the three numerical experiments on the obtained architecture, and the subsequent 634 conclusions.

635 Sub-aerial erosion is mostly limited to carbonate dissolution in Present-day systems (Schlager et al., 2015). Values of $100 \mathrm{~m} /$ Myr or $250 \mathrm{~m} /$ Myr were inferred by Kolodka et al. (2016) and Montaggioni et al. (2015). Considering an emersion period of 0.1 Myr this would lead to a destruction of 10 to $25 \mathrm{~m}$ of platform material, which is up to half of the record for the simulated period on the platform. This is also not in agreement with the remarkable preservation of MIS 5 deposits all around the Bahamas archipelago (Aurell et al., 1995). As a consequence a no-erosion approximation was used in our simulations. This hypothesis provides a very tight control of the subsidence rate parameter.

A more accurate integration of erosion would bring valuable refinements to the problem. Gravity, karstic and wave erosion probably occur at the steep margin wall during subaerial exposure (Grammer and Ginsburg, 1992; Rankey and Doolittle, 2012; Fauquembergue et al., 2018). The interpreted seismic surfaces also show convexe upward geometries at the platform edge that might suggest sub-aerial or wave erosion (Fig. 11B). These geometries are not very well reproduced, showing instead flatter architecture in the experiments (Fig. 11D). Improvement on the use of sub-aerial and shallow water transport model in further experiments could yield better results. The high-resolution production and export balance on the platform is modelled without a specific model of the shallow hydrodynamic regime and transport. As a consequence, the 
independent. They have to be set together to achieve the amount of export required for the slope section in response to a given wave energy configuration at the platform edge. The simulated wave-energy field depends on the margin geometry as it is depth controlled. As the resulting wave energy pattern becomes more favorable, the diffusion coefficient needed for a given flux of sediment decreases The volume of accommodation space is also positively affected by the off-bank export increase. As a result, both the production law and the diffusion coefficient must be jointly decreased in order to maintain the balance between platform accumulation and off-bank export. This is particularly notable for experiment 2, with the existence of a reefal shallow margin that strongly decreases the wave energy at the platform edge. The " aragonite ooze " facies is also produced on a very large platform area, more than $100 \mathrm{~km}$ in W-E length (Harris et al., 2015), but here only a small section of $12 \mathrm{~km}$ is considered. The production values must be artificially raised to account for the actual amount of mud producedon a much larger surface.

As a consequence of the no-erosion hypothesis and the very high platform production values, the accommodation space on the platform is filled very quickly. This differs from the presentday GBB platform that appears partially underfilled (Harris et al., 2015). The total produced volume simulated is directly controlled by the total accommodation space created during a flooding phase. This leads to an overestimation of the sediment accumulation on the platform during a marked transgression like MIS 11 . Then the available accommodation space for the following flooding phase like MIS 9 or 5 is artificially reduced. The discrete sampling of the eustasy curve contributes to this result by missing out the maximum peaks, especially for MIS 5.

676 Here, the influence of contour currents is limited to an open lateral boundary condition. It 677 controls the position of the lower slope periplatform drift in the experiments. The control of 678 the morphology of the periplatform drift by the current action (Betzler et al., 2014; Wunsch et 679 al., 2016) or by gravitational failures (Rendle and Reijmer, 2002; Principaud et al., 2015; 
680

681

682

683

684

685

686

687

688

689

690

691

692

693

694

695

696

697

698

699

700

701

702

703

Principaud et al., 2016; Schnyder et al., 2016) are integrated into the diffusion approximation by the value of the diffusion coefficient for the "aragonite ooze".

\subsection{Mechanisms and controls of the margin progradation}

\subsubsection{Importance of cemented facies at the margin}

All the three modeling experiments show a progradation of the platform for the interval 1.7$0.8 \mathrm{Ma}$ through the construction of a reefal margin (Fig. 7B). After $0.8 \mathrm{Ma}$, only the experiments 2 and 3 show a progradation with an acceptable final profile geometry (Fig. 7C). The accumulation of early cemented material at the margin is essential in these two experiments to obtain these results. However they simulate two different marginal architectures originating from two different sedimentary systems. Experiment 2 is based on the development of marginal fringing reefs and an associated debris talus during platform emersion. This model is able to fill the accommodation space in front of the margin by accumulating material in this zone of steep topography during emersion periods. The resulting general architecture corresponds to a dominantly reefal margin with a filled lagoon. Experiment 3 model is based on the accumulation during highstand periods exclusively of coarse and cemented platform production at the platform edge and on the margin. The resulting general architecture is that of an open platform margin with a deeper prograding escarpment. These are two conceptual hypotheses that can be compared to available observations in the section and other margin depositional models.

\subsubsection{Lithological and stratigraphic characteristics of the prograding} margin

In the model of Grammer and Ginsburg (1992) for the slopes of Tongue of The Ocean, MIS 2-4 lowstand carbonate production is realized by fringing reefs feeding a steep $\left(35-45^{\circ}\right)$ cemented sand and debris talus. In their study on the LBB margin, Hine and Neumann (1977) observed 
reefal growth on the leeward margin during the Holocene transgression. After the platform flooding they are buried however by the leeward export of platform sands. Coral floatstone intervals are observed until MIS 6 (0.19-0.13 Ma) in well Clino (Manfrino and Ginsburg, 2001) as well as several rare occurences of coral debris in the OPD leg 166 cores for the Quaternary (Eberli et al., 1997a) (Fig. 4). All these observations indicate simply the persistence of coral production in fringing reefs (Hine and Neumann, 1977; Grammer and Ginsburg, 1992) after the regional peak of coral extinction described by Reijmer et al. (2002). This does not support the scenario of experiment 2 of a coral reefal margin constantly accumulating during flooding and emersion of the platform.

Indeed the role of coral production in the margin after $0.8 \mathrm{Ma}$ appears much reduced compared to its extent in experiment 2 . The margin is on the contrary dominated by the nonskeletal sand accumulation described by Hine and Neumann (1977) and Wilber et al. (1990) as modelled in experiment 3 .

Interestingly the opposite trend is observed in the Pacific, with an increase in coral reef developpments after MIS 11 (0.42-0.37 Ma) (Montaggioni et al., 2015). Contrasting regional environmental changes might be at play, but most probably the first cause of the relative disparition of coral reefs lies in the onset of large muddy production on the flooded platform (Hine and Neumann, 1977). However during emersion phases this inhibition is absent and coral production can be maintained in fringing reefs as proposed by Grammer and Ginsburg (1992).

Lowstand prograding marginal bodies have been described, by Grammer and Ginsburg (1992) as sandy talus sourced by a fringing reef factory. Mulder et al. (2017) identified possible coarse lowstand shelf-edge tidal deltas or gravity collapse deposits on the northern slope of the LBB . Betzler et al. (2016) also described MIS 2-1 coarse lowstand wedges on the slope of the Maldives atolls. They are dominated by rodoliths and large benthic foraminifers produced in situ. A relevant ancient analogue for lowstand wedges could be found in the Messinian 

marginal reefal clinoforms described by Reolid et al. (2014) in the Cariatiz carbonate platform

731 (Spain). Clinoforms are $80 \mathrm{~m}$ high and $200 \mathrm{~m}$ long bodies, prograding by redistribution of the coral and Halimeda marginal production and through episodes of mass-failure redeposition of very coarse debris during sea level falls. The very steep (30-60 ${ }^{\circ}$ ) upper slope is preserved by early lithification of the corals by microbialith crusts. In regards of these observations the hypothesis in Experiment 2 of coarse lowstand talus, with a fraction of coral component, appears conceivable. These wedges are critical in the experiments for the filling of the accommodation space in front of the margin (Cemented Lowstand Talus in Figure 10). However they do not have the development of the reefal margin observed before $0.8 \mathrm{Ma}$, during a different regime of eustatic oscillations (Manfrino and Ginsburg, 2001; Miller et al., 2011).

According to experiment 3 , the escarpment is the site of accumulation of sandy platform material. This is compatible with the present-day observations on the GBB leeward margin (Wilber et al., 1990). The accumulation at the steep margin by cementation of the platform production would be comparable in geometry to the deep boundstone factory described by Playton et al. (2010). However in this case the progradation of the planar clinoforms of the margin is realized by the accumulation of debris apron resulting from frequent autogenic collapse.Such wedges of marginal progradation are lacking in experiment 3. As this nonskeletal sands observed in the Holocene corresponds only to flooding periods, we propose a conceptual model combining lowstand talus during emersion periods and aggrading platform edge sand bodies during flooding periods (Fig. 10).

As a conclusion the sedimentary accumulation at the margin has changed between $1.7 \mathrm{Ma}$ and the Present-day. It has evolved from a reef-dominated margin to the Present-day cemented sand accumulation. The progradation of the platform before $0.8 \mathrm{Ma}$ has been mostly realized 
by a coral reef barrier. After $0.8 \mathrm{Ma}$ the geometry obtained with experiment 2 is the more

757 consistent with the observed Present-day geometry. It supports a conceptual model of lowstand cemented talus wedges alimented by an undefined carbonate source, possibly reefal in part. It is distinct from the cemented non-skeletal sand accumulation deposited only during platform flooding periods in an aggrading pattern. The progradation of the margin after $0.8 \mathrm{Ma}$ is realized by the succession of these two sandy and early cemented accumulations during emersion and flooding phases (Fig. 10).

\subsubsection{Extrinsic and intrinsic controls}

From the simulations results the interaction between extrinsic and intrinsic factors and the evolution of the margin architecture can be discussed.

The situation before $0.8 \mathrm{Ma}$ of a partial flooding of the platform (Kievmann, 1998) appears more favorable to the progradation than later when the platform is completely flooded during every highstands. The change in the eustatic regime between 0.8 and $0.42 \mathrm{Ma}$ with a net increase of accommodation space is influential in this change of sedimentary regime with the increase of non-skeletal production. After a regressive phase of accumulation on the margin, the sediment deposition is now concentrated on the platform and slope. The second period (0.42-0 Ma) corresponds to an overall increase in accommodation space, with higher amplitude sea-level rises and falls than during the first period and the abrupt transition from a sloping reefal margin to a steep cemented margin. The resulting comprehensive flooding of the GBB platform inhibits coral growth at the margin, and leads instead to the aggrading accumulation of non-skeletal sands at the margin (Fig. 10). This promotes a steepening of the margin profile, accentuating in turn the contrast between total emersion phases, with the development of a steep cemented talus in front of the margin, and the aggradation on the margin during flooding of the whole platform. 

development of a steep marginal escarpment (Wilber et al., 1990; Eberli et al., 2004; Rankey and Doolittle, 2012; Mulder et al., 2017) (Fig. 7). Chabaud et al. (2016) observed a similar major change in sedimentary regime at MIS 11 (0.43$0.37 \mathrm{Ma}$ ) for the northern slope of the LBB, corresponding to the flooding of the whole bank. Remarkably the higher sea-level has led to increased production and export of sediment to the slope (highstand shedding), but only to minor platform progradation (Fig. 6 and Fig. 7A). This modification of the sedimentary regime corresponds to the change of the margin geometry. In turns, it seems to be controlled by the type and mechanical properties of the carbonate production as well as by the eustatic regime. The progradation regime is not controlled primarily by the ratio of production rate and accommodation rate, but by the properties of the carbonate production. As the dominant muddy production cannot accumulate on the steep slopes inherited from the reefal progradation, it is built by early cementation of the coarse accumulations. The reduced volume and the geometry of this sandy platform edge depocenter favour an aggradational stacking pattern as observed in experiment 3 (Fig. 7C).

The activity of the Santaren Current is undoubtedly a major control parameter of the sediment accumulation on the slope and basin, especially of the geometry of slope wedges (Rendle and Reijmer, 2002; Betzler et al., 2014; Principaud et al., 2016; Wunsch et al., 2017; Wunsch et al., 2018). By preventing the sediment accumulation at the toe of slope, it enhances the steepening of the transect indifferently of the progradation or aggradation of the platform edge. It seems actually to have no direct influence on the margin geometry: in Wilber et al. (1990) the geometry of the platform-edge depocenter is very stable for all the transect, whereas the varying slope geometry further down is indeed related to spatial variations in the current activity.The active off-bank density currents (Wilson and Roberts, 1992; Betzler et al., 
aggrading geometry of the platform-edge depocenter. They create erosive plunge-pools at the

807 base of the margin wall (Wilber et al., 1990; Schnyder et al., 2018), and probably limit sedimentary accumulation along the steep wall.

\subsection{Interpretation of the stratigraphic architecture in the seismic}

The high-resolution geometries and stacking patterns simulated with DionisosFlow offer a consistent template of the margin evolution (Fig. 7). The interpretation of the seismic geometries at the margin per se is difficult, as the cored wells do not really constrain the physiography of the margin domain. Moreover the reflectors can be difficult to pick in this area of high-frequency impedance contrasts and variations (Eberli et al., 2004). It is however possible to propose an interpretation of different genetic bodies using the results of the forward stratigraphic modeling (Fig. 11).

817 The seismic section of the margin was analyzed in terms of reflectors terminations: downlap, toplap and onlap distinguishing between coastal onlap due to deposition at the base-level on the platform or the margin and marine onlap due to deposition in the slope underwater. Reflectors with good amplitude and continuity and significant terminations relationships were highlighted. The variations in amplitude of the reflectors in the margin were also used by interpreting the very bright reflectors as indicative of early cementation. SSB $C$ is downlapped by a well-organized prograding unit on the flatter upper margin, with moderate amplitude and low continuity reflectors (Fig. 11B). Deposition is further reduced below 270 ms TWTT, on the steepest part of SSB C profile, down to a lower slope marine onlap at $400 \mathrm{~ms}$ TWTT.

More continuous but lower amplitude reflectors underline a forced regressive architecture, carrying the platform edge down to a remarkable downlapping/onlapping suspended body at 200 ms TWTT. Accumulation is still reduced on the lower margin and the slope (Fig. 11B). As a consequence the steepening of the margin profile increases. This phase seems to end with a general retrogradation of the system highlighted by the development of a cemented surface at 
832 the very edge of the platform. Deposition occurs then on the slope, with new marine onlap,

833 and is also backstepping on the relatively flat platform up to the very bright reflector identified 834 as SSB B (Fig. 11B).

835 This evolution is very consistent with the results of the numerical experiments. The forced 836 regressive evolution between 0.8 and $0.42 \mathrm{Ma}$ (Fig. 6) as well as the final retrogradation during 837 MIS $11(0.42-0.37 \mathrm{Ma})$ are well observed in all the experiments. The new profile of SSB B is 838 more similar to the present-day profile than SSB C (Fig. 11C). .

839

840 Above 180 ms TWTT the geometries appear quite different on the margin (Fig. 11B). Platform-

841 edge bodies, delimited by bright sub-horizontal reflectors and with internal downlaps can be

842 identified with the platform edge depocenters described in Wilber et al. (1990) (Fig. 10). They

843 are onlapped by steep margin wedges with very bright reflectors indicating probably cemented

844 material. In the slope bodies with moderate amplitude and very continuous reflections are 845 onlapping the steep margin (Fig. 11C). Downlapping cemented marginal wedges are observed 846 in the seismic (Fig. 11B) similar to the cemented marginal wedges of experiment 2 (Fig. 7C).

847 Coastal onlaps that indicate an accumulation during platform emersion especially MIS 6-8 and 848 MIS 2-4 (Fig. 11B).

849 The interpretation of the margin stacking pattern in the seismic yields an architecture 850 consistent with the numerical results. The early geometries show the progradation of a reefal 851 margin. The progradation/aggradation after $0.42 \mathrm{Ma}$ appears to involve platform edge bodies 852 and prograding marginal cemented wedges. The observed geometry of the present-day 853 Holocene mud wedge stands out from the earlier MIS 5 or 11 slope periplatform wedge, but it 854 might not correspond to the preserved highstand geometry (Fig. 11C). 


\section{Conclusions}

856 The use of numerical forward stratigraphic modelling allowed us to investigate the high-

857 resolution evolution of the Quaternary leeward margin of the GBB. Maximum information has

858 been extracted from the quality data of the platform and slope wells, as well as the

859 reprocessed seismic of Wunsch et al. (2018) by comparison with the results of several 860 conceptual models.

861 This study has shown that the evolution of the margin during the Quaternary interval of 862 interest $(1.7-0 \mathrm{Ma})$ can be divided in two different phases, with a transition period between 8630.8 and $0.42 \mathrm{Ma}$. The first period $(1.7-0.8 \mathrm{Ma})$ corresponds to a period of partial flooding of 864 the platform and progradation of dominantly coral reef and lagoon system. The second period 865 (0.8-0.42 Ma) corresponds to a period of short and discrete flooding episodes of the whole 866 platform triggering massive muddy offbank transport, and lowstand periods of margin 867 accumulation and progradation.

868 The evolution of the transect architecture during this period cannot be explained only by the offbank transport of the fine-grained platform production. The Present-day sedimentary architecture and profile is actually only indicative of the recent Holocene platform-flooding highstand conditions. It has been shown that different sedimentary regimes have probably existed during the Quaternary not only before MIS 11 transgression (0.42-0.37 Ma) but also after during the long-duration emersion periods.

874 The numerical investigation shed some light on the controls of the margin architecture and the progradation of the platform. The margin profile as interpreted in the seismic and observed at present day seems always due to the marginal accumulation of a cemented or bio-constructed

877 material, different from the fine-grained inner platform-production exported off-bank. This 878 marginal material is well known before $0.8 \mathrm{Myr}$ as a coral reef drilled in Clino. The numerical 879 experiments do not give an unequivocal identification of the undrilled material after this date. 
It shows nevertheless that the Present-day platform edge accumulation of platform sands is

881 not sufficient to explain the architecture of the observed Present-day margin.

882 The experiments demonstrated the role of lowstand marginal accumulation in the progradation of a leeward carbonate margin. A carbonate factory has to be producing and accumulating at the steep margin area during platform emersion. Its characteristics differ from the fine-grained Present-day platform production to be able to accumulate there, meaning coarser grain sizes, cementation or bio-construction. Such a lowstand component is not visible in studies of the slope area, as shown in our experiments, and can be overlooked in the model based primarily on geophysical and sedimentary data from the slope (Principaud et al., 2016b; Wunsch et al., 2016; Wunsch et al., 2018). However coarse and cemented lowstands prisms have been described in recent systems, notably in the Maldives by Betzler et al. (2016) and in the Bahamas by Grammer and Ginsburg (1992). In that latter case the carbonate source proposed was lowstand fringing coral reefs, but other carbonate sources like red algae or large benthic foraminifera could be considered as well (Betzler et al., 2016).

The evolution of the architecture of the platform-to basin transect during the Quaternary appeared controlled by the eustasy as well as the characteristics of the carbon production. Eustasy produces a strong control on the timing of the evolution but the geometry is controlled by the carbonate production. The diffusive DionisosFlow model highlights the critical role of the stability domain of carbonate grains and early cementation (Kenter, 1990; Playton, 2010) to build the steep margin/low angle slope accretionary profile of the GBB leeward slope. The change in carbonate production after 0.42 cannot be disconnected from the evolution of the eustatic regime toward high transgression of 100-kyr cycles. The resulting comprehensive

903 flooding of the platform and large leeward off-bank transport of sediments was probably an 904 important factor in the demise of large coral reefs. The diminishing importance of the coral 905 production is coeval with a reduction of the progradation rate of the system. 
906

907

908

909

910

911

912

913

914

915

916

917

918

919

920

921

922

923

924

925

926

927

928

929

930

931

This high-resolution forward modeling approach could be implemented in on a wider extent on the well mapped Leeward GBB Bahamas slope (Principaud et al., 2016; Wunsch et al., 2018), or other slopes. A 3D approach could fully integrate the effect of the contour currents. This approach could be conducted further for "source-to-sink" estimations of production, transport and deposition balances of sediments in the whole carbonate system. The inputs of the data from the Bahamas Drilling Project wells Clino and Unda (Ginsburg et al., 2001) were invaluable in this study. New subsurface drilling investigations of present-day carbonate margin can bring major insights in the dynamic and controls of carbonate platforms.

\section{ACKNOWLEDGMENTS}

The authors thank Gregor Eberli for his insightful comments and for his discussion on the present-day GBB margin and on the acquisition of the seismic dataset.

This work is sponsored by the TOTAL R\&D in the "Carbonates project » and has been realized in the framework of the Research Chair " Sedimentology and reservoir modelling " funded by TOTAL at IFP School and owned by P. Joseph.

J. Busson's Ph.D. Grant is also funded by TOTAL.

\section{DECLARATION OF INTERESTS: none}

\section{REFERENCES CITED}

Anselmetti, F. S., Eberli, G. P., Ding, Z. D., 2000. From the Great Bahama Bank into the Straits of Florida: A margin architecture controlled by sea-level fluctuations and ocean current. Bulletin of the Geological Society of America 112 (6), 829-844. 
932 Aurell, M., McNeill, D. F., Guyomard, T., \& Kindler, P., 1995. Pleistocene Shallowing-Upward 933 Sequences in New Providence, Bahamas: Signature of High-Frequency Sea-Level Fluctuations 934 in Shallow Carbonate Platforms. Journal of Sedimentary Research, 65B (1b), 170-182.

935 Aurell, M., Badenas, B., Bosence, D. W. J., Waltham, D. A., 1998. Carbonate production and 936 offshore transport on a Late Jurassic carbonate ramp (Kimmeridgian, Iberian basin, NE Spain): 937 evidence from outcrops and computer modelling. Geological Society, London, Special 938 Publications 149 (1), 137-161.

939 Berra, F., Lanfranchi, A., Smart, P. L., Whitaker, F. F., \& Ronchi, P., 2016. Forward modelling of 940 carbonate platforms: Sedimentological and diagenetic constraints from an application to a flat941 topped greenhouse platform (Triassic, Southern Alps, Italy). Marine and Petroleum Geology $94278,636-655$.

943 Betzler, C., Reijmer, J. J. G., Bernet, K., Eberli, G. P., Anselmetti, F. S., 1999. Sedimentary 944 patterns and geometries of the Bahamian outer carbonate ramp (Miocene-Lower Pliocene, 945 Great Bahama Bank). Sedimentology 46 (6), 1127-1143.

946 Betzler, C., Lindhorst, S., Eberli, G. P., Lüdmann, T., Möbius, J., Ludwig, J., ... Hübscher, C., 2014. 947 Periplatform drift: The combined result of contour current and off-bank transport along 948 carbonate platforms. Geology $42(10), 871-874$.

949 Betzler C., Hübscher C., Lindhorst S., Lüdmann T., Reijmer J. J.G., Braga J.-C., 2016. Lowstand 950 wedges in carbonate platform slopes (Quaternary, Maldives, Indian Ocean). The Depositional Record 20162 (2), 196-207 Budd, A. F., \& Manfrino, C. M., 2001. Coral assemblages and reef environments in the Bahamas Drilling Project Cores. In Subsurface Geology of a Prograding Carbonate Platform Margin, Great

954 Bahama Bank: Results of the Bahamas Drilling Project 70, 41-60.

955 Caspard, E., Rudkiewicz, J. L., Eberli, G. P., Brosse, E., Renard, M., 2004. Massive dolomitization 956 of a Messinian reef in the Great Bahama Bank: A numerical modelling evaluation of Kohout 957 geothermal convection. Geofluids 4 (1), 40-60. 
Sedimentary processes determining the modern carbonate periplatform drift of Little Bahama Bank. Marine Geology 378, 213-229.

Csato, I., Catuneanu, O., Granjeon, D., 2014. Millennial-Scale Sequence Stratigraphy: Numerical Simulation With Dionisos. Journal of Sedimentary Research 84 (5), 394-406. platforms, northwestern Great Bahama Bank. Geology 15 (1), 75-79.

Eberli, G. P., 1988. 21. Physical properties of carbonate turbidite sequences surrounding the Bahamas - implication for slope stability and fluid movements. In Austin J.A., Jr., Schlager, W. et al., Proceedings of the Ocean Drilling Program. Scientific results 101, 305-314.

Eberli, G.P., Swart P.K., Malone M.J., and al., 1997a. Proceedings of the Ocean Drilling Program, Initial Reports, 166. Ocean Drilling Program. College Station, TX.

Eberli, G.P., Swart, P. K., McNeill, D. F., Kenter, J.A.M, Anselmetti, F.S., Melim, L.A., Ginsburg, R.N., 1997b. A synopsis of the Bahamas Drilling Project: Results from two deep core borings drilled on the Great Bahama Bank. In Eberli, G.P., Swart, P.K., Malone, M.J., et al. (Eds) Proceedings of the Ocean Drilling Program. Initial Reports. Leg 166. Ocean Drilling Program. College Station, TX.

Eberli G.P., 2000. 16. The record of Neogene sea-level changes in the prograding carbonates along the Bahamas transect - Leg 166 synthesis, in Swart P.K., Eberli G.P., Malone M.J., and Sarg J.F. (Eds.), Proceedings of the Ocean Drilling Program, Scientific. Results. Vol. 166 Seismic Sequence Stratigraphy with Cores and Logs in Subsurface Geology of a Prograding

980 Carbonate Platform Margin, Great Bahama Bank: Results of the Bahamas Drilling Project 70.

981 Eberli, G. P., Anselmetti, F. S., Kroon, D., Sato, T., Wright, J. D., 2002. The chronostratigraphic signicance of seismic reflections along the Bahamas Transect. Marine Geology 185, 1-17. 
984 Carbonate Platform to Basin Transitions on Seismic Data and in Outcrops: Great Bahama Bank and the Maiella Platform Margin, Italy. Seismic Imaging of Carbonate Reservoirs and Systems: AAPG Memoir 81, 207-250.

Eberli, G. P., 2013. The uncertainties involved in extracting amplitude and frequency of orbitally driven sea-level fluctuations from shallow-water carbonate cycles. Sedimentology 60 (1), 64-84.

990

Fauquembergue, K., Ducassou, E., Mulder, T., Hanquiez, V., Perello, M. C., Poli, E., Borgomano,

J. 2018. Genesis and growth of a carbonate Holocene wedge on the northern Little Bahama Bank. Marine and Petroleum Geology 96, 602-614.

Ginsburg, R. N., 2001. Subsurface geology of a prograding carbonate platform margin, Great Bahama Bank: Results of the Bahamas Drilling Project. SEPM Special Publications 70 Grammer, G. M., Ginsburg, R. N., 1992. Highstand versus lowstand deposition on carbonate platform margins: insight from Quaternary foreslopes in the Bahamas. Marine Geology, 103(13), 125-136.

Granjeon, D., Joseph, P., 1999. Concepts and applications of a 3D multiple lithology, diffusive model in stratigraphic modeling. SEPM Special Publication 62(May), 197-210. Granjeon, D., 2014. 3D forward modelling of the impact of sediment transport and base level cycles on continental margins and incised valleys. In Martinius, A. W., Ravnås, R. , Howell R. J., ,Steel, J. A.,Wonham J. P., From Depositional Systems to Sedimentary Successions on the Norwegian Continental Margin. International Association of Sedimentologists. Gent. Harris, P. M. M., Purkis, S. J., Ellis, J., Swart, P. K., Reijmer, J. J. G., 2015. Mapping bathymetry and depositional facies on Great Bahama Bank. Sedimentology, 62 (2), 566-589. diagenesis of Pleistocene highstand sediments from the Bahamas slope. Proceedings of the 1008 Ocean Drilling Program: Scientific Results 166, 23-31. 
Hine, A. C. Neumann, A.C., 1977. Shallow carbonate-bank-margin growth and structure, Little

1010 Bahama Bank, Bahamas. AAPG Bulletin 61 (3), 376-406.

1011

Hunt, D., Tucker, M. E., 1992. Stranded parasequences and the forced regressive wedge systems tract: deposition during base-level fall. Sedimentary Geology 81 (1-2), 1-9.

1013 Hunt, D., Tucker, M., 1993. The middle Cretaceous Urgonian platform of southeastern France, in Simo, J. A. T., Scott, R. W., Masse, J-P., Cretaceous Carbonate Platforms, American Association of Petroleum Geologist 56, 409-453.

1016

Jo, A., Eberli, G. P., \& Grasmueck, M., 2015. Margin collapse and slope failure along southwestern Great Bahama Bank. Sedimentary Geology 317, 43-52. Kenter, J. A. M., 1990. Carbonate platform flanks: slope angle and sediment fabric. Sedimentology 37 (5), 777-794.

Kenter, J. A. M., Ginsburg, R. N., \& Troelstra, S. R., 2001. Sea-level-driven sedimentation patterns on the slope and margin. In Subsurface Geology of a Prograding Carbonate Platform Margin, Great Bahama Bank. Results of the Bahamas Drilling Project 70, pp. 61-100.

1023 Kievman, C. M. 1998. Match between late Pleistocene Great Bahama Bank and deep-sea oxygen isotope records of sea level. Geology 26 (7), 635-638.

1025

Kolodka, C., Vennin, E., Bourillot, R., Granjeon, D., Desaubliaux, G., 2016. Stratigraphic modelling of platform architecture and carbonate production: a Messinian case study (Sorbas Basin, SE Spain). Basin Research 28 (5), 658-684.

1028 Lanteaume C., Fournier F., Borgomano J., Pellerin M., Testing geological assumptions and experiments in carbonate exploration: insights from integrated stratigraphic, diagenetic and seismic forward modeling, Leading Edge 37 (9), 672-680.

1031 Lavoie, D.,1988. Geotechnical properties of sediments in a carbonate-slope environment:

1032 Ocean drilling Program site 630, Northern Little Bahamas Bank, in Austin, J. A., Jr., Schlager, 1033 W., et al., Proceedings of the Ocean Drilling Program, Scientific Results, 101 
Lisiecki, L. E., \& Raymo, M. E., 2005. A Pliocene-Pleistocene stack of 57 globally distributed

1050

1051

1052

1053

1054

1055

1056

benthic $\delta 180$ records. Paleoceanography 20 (1), 1-17.

Malone, M. J., Slowey, N. C., \& Henderson, G. M., 2001. Early diagenesis of shallow-water periplatform carbonate sediments, leeward margin, Great Bahama Bank (Ocean Drilling Program Leg 166). Bulletin of the Geological Society of America 113 (7), 881-894.

Macllreath I.A., James N.P., 1978. Facies Models 13. Carbonate slopes. Geoscience Canada 5, 4, 189-199

Manfrino, C. M., \& Ginsburg, R. N., 2001. Pliocene to Pleistocene deposition history of the Upper Platform Margin. Subsurface Geology of a Prograding Carbonate Platform Margin, Great Bahama Bank: Results of the Bahamas Drilling Project 70, 17-40.

Mcneill, D. F., Eberli, G. P., Lidz, B. H., Swart, P. K., \& Kenter, J. A. M. , 2001. Chronostratigraphy of a prograded carbonate platform margin: a record of dynamic slope sedimentation, Western Great Bahama Bank. In Subsurface Geology of a Prograding Carbonate Platform Margin, Great Bahama Bank: Results of the Bahamas Drilling Project 70, pp. 101-136.

Melim, L. A., Westphal, H., Swart, P. K., Eberli, G. P., Munnecke, A. , 2002. Questioning carbonate diagenetic paradigms: Evidence from the Neogene of the Bahamas. Marine Geology $185(1-2), 27-53$.

Miller, K.G., G.S. Mountain, J.D. Wright, and J.V. Browning., 2011. A 180-million-year record of sea level and ice volume variations from continental margin and deep-sea isotopic records. Oceanography $24(2), 40-53$.

Montaggioni, L. F., Borgomano, J., Fournier, F., Granjeon, D., 2015. Quaternary atoll development: New insights from the two-dimensional stratigraphic forward modelling of Mururoa Island (Central Pacific Ocean). Sedimentology 62 (2), 466-500.

Mulder T., Alexander J., 2001. Abrupt change in slope causes variation in the deposit thickness of concentrated particle-driven density currents. Marine Geology 175, 221-235. 
Mulder, T., Ducassou, E., Eberli, G. P., Hanquiez, V., Gonthier, E., Kindler, P., Pakiades, M. , 1060 2012. New insights into the morphology and sedimentary processes along the western slope of Great Bahama Bank. Geology 40 (7), 603-606.

1062

Mulder, T., Joumes, M., Hanquiez, V., Gillet, H., Reijmer, J. J. G., Tournadour, E., ... Busson, J.

1063 ,2017. Carbonate slope morphology revealing sediment transfer from bank-to-slope (Little Bahama Bank, Bahamas). Marine and Petroleum Geology 83, 26-34.

1065

Mullins H.T., Neumann A.C., Wilber R.J., Boardman M.A., 1980. Nodular Carbonate sediment

1066 on Bahamian slopes: possible precursors to nodular limestones. Journal of Sedimentary Petrology $50 \mathrm{I}, 0117-0131$.

1068

Mullins, H. T., Wise, S. W., Gardulski, A. F., Hinchey, E. J., Masters, P. M., \& Siegel, D. I., 1985.

Shallow subsurface diagenesis of Pleistocene periplatform ooze: northern Bahamas. Sedimentology 32 (4), 473-494.

1071

Mullins H.T., Cook, H. E., 1986. Carbonate apron models: alternative to the submarine fan model for paleoenvironmental analysis and hydrocarbon exploration. Sedimentary Geology 48, $37-79$

1074

Munnecke, A., Westphal, H., Reijmer, J. J. G., Samtleben, C. , 1997. Microspar development 1075 during early marine burial diagenesis: A comparison of Pliocene carbonates from the Bahamas with Silurian limestones from Gotland (Sweden). Sedimentology 44 (6), 977-990.

1077 Playton, T. E., Janson, X., Kerans, C., 2010. Carbonate Slopes 18. In James, N. P., Dalrymple, R. W. (Eds.), Facies 4. Geological Association of Canada. St. John's, Newfoundland, Canada, 449476. Pomar, L., Haq, B. U., 2016. Decoding depositional sequences in carbonate systems: Concepts vs experience. Global and Planetary Change 146, 190-225.

1082 Principaud, M., Mulder, T., Gillet, H., Borgomano, J., 2015. Large-scale carbonate submarine 1083 mass-wasting along the northwestern slope of the Great Bahama Bank (Bahamas): 1084 Morphology, architecture, and mechanisms. Sedimentary Geology 317, 27-42. 

basin stratigraphic evolution of the northwestern Great Bahama Bank (Bahamas) during the Neogene to Quaternary: interactions between downslope and bottom currents deposits. Basin Research 29 (6), 699-724.

1089

Principaud, M., Mulder, T., Hanquiez, V., Ducassou, E., Eberli, G., Chabaud, L., Borgomano, J., 1090 2018. Recent morphology and sedimentary processes along the western slope of Great Bahama Bank (Bahamas). Sedimentology 65 (6), 2088-2116

1092

Rabineau, M., Berne, S., Aslanian, D., Olivet, J.-L., Joseph, P., Guillocheau, F., Bourillet, J.-F., 1093 Ledrezen, E., Granjeon, D., 2005. Sedimentary sequences in the Gulf of Lion: A record of 100,000 years climatic cycles. Marine and Petroleum Geology. 22 (6-7), 775-804

1095

Rankey, E. C., Doolittle, D. F., 2012. Geomorphology of carbonate platform-marginal uppermost slopes: Insights from a Holocene analogue, Little Bahama Bank, Bahamas. Sedimentology 59 (7), 2146-2171.

Reijmer, J., Betzler, C., Kroon, D., Tiedemann, R., Eberli, G.,2002. Bahamian carbonate platform development in response to sea-level changes and the closure of the Isthmus of Panama. International Journal of Earth Sciences 91 (3), 482-489.

1101 Reijmer, J. J. G., Mulder, T., Borgomano, J., 2015. Carbonate slopes and gravity deposits. Sedimentary Geology 317, 1-8.

1103 Rendle, R. H., Reijmer, J. J. G., Kroon, D., \& Henderson, G. M., 2000. 6. Mineralogy and Sedimentology of the Pleistocene to Holocene on the Leeward Margin of Great Bahama Bank. In Swart, P.K., Eberli, G.P., Malone, M.J., and Sarg, J.F. (Eds.), 2000 Proceedings of the Ocean Drilling Program, Scientific Results 166. margin of the Great Bahama Bank. Marine Geology 185 (1-2), 143-164. 
1109 Reolid, J., Betzler, C., Braga, J. C., Martín, J. M., Lindhorst, S., \& Reijmer, J. J. G., 2014. Reef 1110 slope geometries and facies distribution: Controlling factors (Messinian, SE Spain). Facies 60 1111 (3), 737-753.

1112 Schlager, W., \& James, N. P., 1978. Low-magnesian calcite limestones forming at the deep-sea floor, Tongue of the Ocean, Bahamas. Sedimentology 25 (5), 675-702. Schlager, W. and Ginsburg, R.N., 1981. Bahama carbonate platforms: the deep and the past. In M.B. Cita and W.B.F. Ryan (Eds), Carbonate Platforms of the Passive-Type Continental Margins, Present and Past. Mar. Geol. 44, 1-24. Schlager, W., Reijmer, J. J. G., \& Droxler, A., 1994. Highstand Shedding of Carbonate Platforms. Journal of Sedimentary Research B64 (3), 270-281. Schlager, W., 2005. Carbonate Sedimentology and Sequence Stratigraphy. SEPM Concepts in 1120 Sedimentology and Paleontology 8.

1121 Schnyder, J. S. D., Eberli, G. P., Betzler, C., Wunsch, M., Lindhorst, S., Schiebel, L., Ducassou, E 1122 and al., 2018. Morphometric analysis of plunge pools and sediment wave fields along western Great Bahama Bank. Marine Geology 397, 15-28.

Seard, C., Borgomano, J., Granjeon, D., Camoin, G., 2013. Impact of environmental parameters on coral reef development and drowning: Forward modelling of the last deglacial reefs from Tahiti (French Polynesia; IODP Expedition \#310). Sedimentology 60 (6), 1357-1388. Spence, G. H., Tucker, M. E., 1997. Genesis of limestone megabreccias and their significance in carbonate sequence stratigraphic models: a review. Sedimentary Geology 112 (3), 163-193. stratigraphic forward modelling for analysis and prediction of carbonate platform

1131 stratigraphies in exploration and production. Marine and Petroleum Geology 25 (1), 35-58.

1132 Wilber, R. J., Milliman, J. D., \& Halley, R. B.,1990. Accumulation of bank-top sediment on the 1133 western slope of Great Bahama Bank: rapid progradation of a carbonate megabank. Geology. 
1134 Wilson, P. A., \& Roberts, H. H., 1992. Carbonate-periplatform sedimentation by density flows:

1135 a mechanism for rapid off-bank and vertical transport of shallow-water fines. Geology 20 (8),

$1136713-716$

1137 Wunsch, M., Betzler, C., Lindhorst, S., Lüdmann, T., \& Eberli, G. P., 2017. Sedimentary dynamics along carbonate slopes (Bahamas archipelago). Sedimentology 64 (3), 631-657. Sedimentary dynamics and high-frequency sequence stratigraphy of the southwestern slope of Great Bahama Bank. Sedimentary Geology 363, 96-117.

\section{TABLE CAPTIONS}

Table 1: Age, Depth and time position of this study stratigraphic markers in the six wells, compared with the previous publications on this transect.

Table 2: The five lithofacies identified in the six wells of the study, with their lithology, depositional environment and, mineralogic and diagenetic fabric. Table 3: Values of transport coefficients for the DionisosFlow simulation. Table 4: Definition of the simulated lithofacies from the output of the DionisosFlow simulations.

Figure 1. A: General location of the Great Bahama Bank (GBB) and the leeward western slope.

1159 In orange, the area surveyed by the Carambar Leg 1 mission (Mulder et al., 2012), with, in red, 
the interpreted transect. B: Multibeam bathymetry of the western GBB slope (Principaud et al., 1161 2016) with the position of the "Western line" Seismic transect (Eberli and Ginsburg, 1987), the ODP 166 Wells (Eberli et al., 1997a) and the BDP Platform wells (Ginsburg et al., 2001). Figure 2. "Western Line " platform to basin seismic transect and the six reference wells. A: Original seismic data. B: Sedimentary sequences interpreted on the Western line, following Eberli et al., 1997a nomenclature. The six post-Miocene seismic sequences interpreted by Eberli et al., 1997b are displayed. The "Quaternary" (1.7 - 0 Myr) refers here to the specific interval studied here. The seismic data come, from left to right, from the Carambar $1 \mathrm{HR}$ data published in Principaud et al., 2016; in the box, the reprocessing of the "Western line" original acquisition published by Wunsch et al., 2018, superimposed on the original "Western Line" data as published by Eberli and Ginsburg, 1987.

Figure 3. Present-day geometry of the leeward GBB margin, after Wilber et al. (1990), and geometrical implications for the stacking pattern. A: Observed Schematic section of the depositional geometry for the Holocene and the previous interglacial stage, after the drawing of Eberli et al. (2004; Figure 17 C) and the section of Wilber et al. (1990; Fig. 3). B: Conceptual scheme of the aggrading stacking pattern resulting from the accumulation of the Holocene deposits of A) minimizing the supplementary material needed. C: Conceptual prograding stacking pattern resulting from the accumulation of the Holocene deposits of A) plus supplementary material in the marginal zone.

Fig. 4. Well correlation for the ODP wells 1003 to 1005 and the two BDP wells Clino and Unda showing the lithofacies interpretation corresponding to table see Table 2) and the identified stratigraphic markers (described in section 2.1). Left-top corner: Wells positions in the "Western Line" (see Fig. 1B and Fig. 2).

1183 For the BDP wells Clino and Unda, from left to right, we present the interpreted lithofacies and 1184 the detailed lithological description of Manfrino and Ginsburg (2001). For the ODP 166 wells, 1185 from left to right, the interpreted lithofacies and the lithological description of Eberli et al. 
1186 (1997), for well 1005 the ODP Vp seismic velocity (core (red) and log (black) data of Eberli et al.

1187 (1997a)), and the XRD mineralogical composition modified from Eberli et al. ( 1997a).In the middle the time evolution of the accommodation on platform calculated from the eustatic curve of Miller et al. (2011) with our hypothesis of constant subsidence rate of $34.1 \mathrm{~m} / \mathrm{Myr}$.

Figure 5. Schematic of the three experimental designs for the DionisosFlows simulations after 0.8 Myr. Befor this date they are all similar to Experiment 2.

Figure 6. DionisosFlow production laws. Left: the normalized production profiles for the three producers. Right: time evolution of the maximum production value for the three producers, with the difference between Exp.2 and Exp 1\&3 for the aragonite ooze production. The production of the CCPE facies (in Exp. 3) is discontinuous with time.

Figure 7. Simulated sections at 0 Myr. A: Age results for the three experiments, following the color chart presented in D). B: Lithofacies results for the three experiments, according to table 3.The black line indicates the observed present-day profile. C: Detail view of the age results of the experiments for the margin and slope. D: Eustatic Sea-level variations for the simulated interval, after Miller et al. (2011) in black line, and selected data points for the DionisosFlow simulation (in red). The color indicates different time periods, corresponding after 0.8 Myr to MIS 19 to 1.

Figure 8. Wheeler diagram for the three experiments results, expressing the sedimentation rate. The position of the wells is indicated. On the right the eustatic sea-level variations for the simulated interval, after Miller et al. (2011) in black line, and selected data points for the DionisosFlow simulation (in red). The color indicates different time periods, corresponding after 0.8 Myr to MIS 19 to 1.

1208 Figure 9. Basin to platform well correlation showing side by side the interpreted well and 1209 modelled deposits at the well location (right and left, respectively). The interpreted lithofacies 1210 log is represented on the right. On the left the simulated lithofacies column is shown, with the 
1211 " aragonite ooze " facies composition log (solid line) in opposition to the sedimentation rate $1212 \log$ (in dashed black line).

1213 Figure 10. Conceptual model of margin and slope architecture for the GBB leeward slope 1214 during the 100-kyr large sea-level oscillation period (0.45 - 0 Myr)

1215 Figure 11. High-resolution seismic interpretation for the GBB leeward margin on the data from 1216 Wunsch et al. (2018) and Eberli and Ginsburg (1987). From top to bottom: A) original seismic 1217 data, B) High-resolution interpretation, with the downlap (red), toplap (blue), marine onlap 1218 (light blue) and coastal onlap (light green). The colored line corresponds to the seismic surfaces 1219 identified by Eberli et al. (1997a), the black line to the additional time-line reflectors identified 1220 in this study. C) The interpreted margin section, with the stratigraphic stages colored as in 1221 Fig.7. D) Simulated margin section from Experiment 2, with the same time-color code from fig. 1222 7. This section is a projection of the seismic line orthogonal to the slope, therefor the 1223 bathymetric profile is steeper and the horizontal scales are not matched. TABLES \& FIGURES 
